\title{
ANALISIS PERANCANGAN SISTEM INFORMASI AKUNTANSI PENJUALAN DAN PENERIMAAN KAS PADA PERUSAHAAN
}

\author{
Noerlina; I Gusti Made Karmawan; Nosyar Rahadi \\ Jurusan Komputerisasi Akuntansi, Fakultas Ilmu Komputer, Bina Nusantara University \\ Jln. KH Syahdan No. 9, Kemanggisan, Jakarta Barat 11480 \\ nurlina@binus.edu
}

\begin{abstract}
The objective of writing this paper is to find weaknesses in a sales information system and company income cash; and also to try to suggest a new system design so it could increase the information quality and help reducing existed problems. The method used is data collecting, analysis, and designing method by using data flow diagram, structured diagram, flow chart, and entity relationship diagram. The expected result is the better information quality and easiness in searching transactions. Therefore it could be concluded that by increasing information quality, the decision making quality could also be increased. Besides, system could ease management in searching sales and cash income information.
\end{abstract}

Keywords: analysis, design, accounting information system, sales, cash income.

\begin{abstract}
ABSTRAK
Tujuan penulisan paper ini adalah untuk menemukan kelemahan yang ada pada sistem informasi penjualan dan penerimaan kas Perusahaan dan mencoba mengusulkan rancangan sistem yang baru supaya sistem tersebut dapat meningkatkan kualitas informasi sehinggga dapat membantu mengurangi permasalahan yang ada. Metode yang digunakan adalah metode pengumpulan data, metode analisa dan metode perancangan dengan menggunakan Data Flow Diagram, Diagram Terstruktur,Flow Chart dan Entity Relationship Diagram. Hasil yang dicapai adalah kualitas informasi yang lebih baik dan kamudahan dalam mencatat dan melacak transaksi transaksi yang terjadi. Simpulan yang dapat ditarik dari analisa yang dilakukan adalah dengan meningkatnya kualitas informasi, maka dapat meningkatkan kualitas pengambilan keputusan. Selain itu sistem dapat mempermudah menajemen dalam mencari informasi penjualan dan penerimaan kas.
\end{abstract}

Kata kunci: analisa, perancangan, sistem informasi akuntansi, penjualan, penerimaan kas. 


\section{PENDAHULUAN}

Seiring dengan perkembagannya, perusahaan pasti mengalami perkembangan aktifitas bisnis. Perkembangan aktifitas bisnis mengakibatkan peningkatan jumlah data dan akan memerlukan kapasitas penyimpanan yang lebih besar, aktifitas akan menjadi semakin kompleks dan pengendalian akan semakin sulit. Oleh karena itu perlu melakukan prosedur administrasi yang baik agar aktifitas lebih terorganisir dan data tersimpan dengan baik dan selalu tersedia sewaktu waktu diperlukan. Dapat dibayangkan dengan semakin pesatnya pertumbuhan perusahaan semakin banyak data penting perusahaan yang membutuhkan perhatian. Apalagi data yang dihasilkan oleh aktifitas bisnis perusahaan saling terkait satu sama lainnya dengan aktifitas bisnis lainnya. Oleh karena itu perlu dibuat suatu otomasi prosedur yang dapat mengolah data mengenai aktifitas bisnis perusahaan, menyimpannya, dan mendistribusikannya.

Untuk membantu sebuah sistem yang handal dan kokoh serta dengan kebutuhan perusahaan, tentu tidaklah semudah yang dibayangkan. Pembangunan sistem ini akan menguras benyak waktu, tenaga, pikiran serta biaya. Juga janganlah dilupakan kesabaran dan ketelitian yang harus dimiliki untuk memperbaiki secara terus-menerus sistem yang ada sehingga selalu dapat memenuhi kebutuhan perusahaan. Hal ini memang tidak mutlak untuk dilakukan. Tetapi dengan adanya sistem yang solid, sebuah perusahaan akan dapat bertahan hidup ditengah ketatnya persaingan.

Aktivitas penjualan dalam sebuah perusahaan dagang dapat dikatakan sebagai aktivitas utama. Sebab tanpa adanya penjualan, sebuah perusahaan dagang dapat di katakan mati. Penjualan itu sendiri dapat dikategorikan menjadi dua jenis, yaitu tunai dan kredit. Piutang sendiri erat kaitannya dengan penjualan secara kredit. Kurang baiknya pengelolaan terhadap piutang dapat berakibat macetnya penerimaan kas perusahaan yang dapat mengakibatkan perusahaan tidak mempunyai kas yang cukup untuk melaksanakan aktivitasnya.

Perusahaan ini bergerak di bidang pembuatan dan perakitan alat berat crane dan hoist. Penjualan hoist maupun crane dilakukan berdasarkan pemesanan. Dalam melakukan pelacakan atas transaksi yang telah terjadi sering kali perusahaan dihadapkan dengan berbagai kendala seperti belum tersedianya data, data yang hilang atau rusak, ataupun data yang ada namun sulit untuk dicari. Hal ini terutama terjadi pada fungsi penjualan, penagihan, dan penerimaan kas.

Terkadang dalam penjualan crane, harga yang diberikan ke pelanggan tidak sesuai dengan biaya yang dikeluarkan oleh perusahaan untuk membuat crane tersebut sehingga pelanggan sering dibingungkan dengan adanya perubahan harga. Hal ini disebabkan karena pada saat pemesanan konstruksi, pelanggan memberikan perkiraan spesifikasi konstruksi. Spesifikasi konstruksi yang diberikan oleh pelanggan sering kali tidak sesuai dengan spesifikasi yang sebenarnya dibutuhkan konstruksi. Survei atas spesifikasi konstruksi dimulai setelah terjadinya penjualan artinya, harga sudah jadi dan pelanggan telah memenuhi down payment yang disyaratkan. Bagian penagihan seringkali dibingungkan oleh harga konstruksi yang berubah sehingga jumlah yang ditagh ke pelanggan tidak sesuai dengan yang seharusnya. Oleh karena penulis menyimpulkan bahwa perusahaan memerlukan suatu otomasi sistem yang terkomputerisasi yang dapat menghandel aktifitas penjualan dan penerimaan kas perusahaan.

\section{Ruang Lingkup}

Dalam paper ini penulis akan membahas khususnya mengenai revenue cycle (siklus pendapatan) yaitu suatu rangkaian aktivitas bisnis dan pengolahan informasi yang berkaitan dengan penyediaan barang dan jasa kepada pelanggan dan menerima pembayaran atas penjualan tersebut, dan sistem informasi akuntansi secara umum. Informasi yang didapat dari transaksi ini akan dituangkan ke 
dalam satu integrated database yang dapat diakses oleh siklus siklus sistem informasi akuntansi yang lain yaitu expenditure cycle, production cycle, human resources and payroll cycle, dan general ledger and reporting system. Karena Perusahaan ini belum memiliki sistem informasi akuntansi yang baik, maka penulis dengan segala keterbatasan dan kekurangan akan berusaha untuk membangun sistem informasi akuntansi yang layak yang akan dituangkan dalam paper ini.

Dalam paper ini penulis membatasi ruang lingkup penelitian, dengan transaksi yang meliputi (1) transaksi pemesanan hoist, konstruksi, atau hoist dan konstruksi oleh pelanggan. Sistem sebelumya akan memvalidasi pemesanan yang dilakukan oleh pelanggan apakah pesanan diterima atau ditolak; (2) transaksi penjualan. Maksudnya adalah terjadinya persetujuan pelanggan terhadap surat penawaran yang diajukan perusahaan. Persetujuan ini ditandai dengan dikeluarkannya purchase order oleh pelanggan. Pelanggan menerima faktur yang dikeluarkan oleh sistem sebagai bukti hutang atas pembelian yang dilakukannya; (3) transaksi penerimaan kas. Pembayaran pelanggan diinput ke dalam sistem, diproses oleh sistem kemudian dikeluarkan bukti pembayarannya; (4) otomatisasi penjurnalan atas transaksi panjualan dan penerimaan kas; (5) pembuatan laporan atas transaksi penjualan dan penerimaan kas yang telah terjadi; (6) membahas mengenai aktifitas proses pendapatan dari penerimaan kas yang berasal dari penjualan dengan asumsi telah dilakukan survey atas kredibilitas pelanggan dalam membayar utang.

\section{Tujuan dan Manfaat}

Tujuan paper ini adalah menganalisis sistem penjualan dan penerimaan kas yang berjalan, serta merumuskan permasalahan yang ada, mengidentifikasi kebutuhan informasi berdasarkan analisis pada sistem perusahaan dimana informasi yang dibutuhkan adalah informasi penjualan dan penerimaan kas, memperbaiki kesalahan kesalahan yang ditemukan dalam sistem perusahaan, dan merancang suatu sistem yang berbasis komputer untuk mengatasi permasalahan permasalahan yang ada pada perusahaan dana membantu dalam menghasilkan informasi informasi yang dibutuhkan oleh perusahaan.

Selain itu, manfaat paper ini adalah agar dapat memaksimalkan kerja sistem yang ada pada perusahaan serta mengurangi hambatan hambatan yang ada pada perusahaan, dengan adanya sistem perusahaan yang terkomputerisasi, dapat menghasilkan informasi penerimaan kas untuk memudahkan perusahaan mengetahui pendapatan perusahaan, serta dapat menghasilkan informasi penjulan produk perusahaan.

\section{METODE}

Dalam penulisan paper ini, penulis menggunakan metode analisis dan perancangan, yaitu menganalisis sistem yang sedang berjalan untuk menemukan kekurangan kekurangan dan merancang sistem yang baru agar dapat menutupi kekurangan kekurangan tersebut.

Analisis sistem dilakukan melalui empat tahapan yaitu (1) survei atas sistem yang sedang berjalan, (2) Analisis terhadap temuan survei, (3) Identifikasi kebutuhan Informasi, dan (4) Identifikasi persyaratan sistem. Hasil analisis kemudian dibuat laporannya untuk dimasukan ke dalam perancangan sistem yang diusulkan. Sementara itu, dalam metode perancangan yang digunakan adalah Metode Perancangan Terstruktur melalui tahapan : (1) Pembuatan DFD, (2) Pembuatan Kamus Data, (3) Pembuatan ERD, (4) Pembuatan Bagan Terstruktur dan (5) Pembuatan Rancangan Masukan dan Keluaran. Obyek penelitian adalah struktur organisasi perusahaan, manual, prosedur tertulis, dan aturan yang ada, dan pimpinan dan staf di bagian akunting, keuangan dan penjualan. 
Adapun pengumpulan datanya dilakukan dengan cara riset kepustakaan dan riset lapangan. Riset kepustakaan dilakukan dengan mempelajari buku-buku atau literatur-literatur yang berkaitan dengan sistem informasi akuntansi serta sumber-sumber lain yang berhubungan dengan masalah yang dibahas oleh penulis. Sementara itu, riset lapangan dilakukan dengan mengadakan peninjauan langsung pada Perusahaan sebagai objek penelitian. Teknik yang digunakan adalah wawancara dan observasi. Wawancara dengan cara mengajukan pertanyaan-pertanyaan secara langsung kepada pihak yang terlibat dalam siklus pendapatan. Observasi dengan cara mengadakan pengamatan secara langsung terhadap sistem yang sedang berjalan. Data yang diperoleh dari hasil wawancara, dan observasi dikumpulkan bersama. Kemudian data tersebut dianalisa dengan cara membuat diagram aliran (flow chart). Dengan cara ini dapat diketahui tentang bagaimana sistem, apa permasalahannya, dan apa kebutuhannya. Berdasarkan hasil analisis yang telah kami lakukan mengenai sistem penjualan dan penerimaan kas pada Perusahaan, maka kami memberikan kesimpulan bahwa keadaan Perusahaan dapat disimpulkan: (1) perusahaan menggunakan sistem penjualan berdasarkan pesanan dalam kegiatan usahanya dan sistem persediaan perusahaan adalah berdasarkan just in time; (2) hanya beberapa dokumen yang digunakan dalam transaksi penjualan perusahaan sudah bernomor urut tercetak. Penomeran ini dilakukan dengan menggunakan stempel penomeran manual; (3) sistem informasi akuntansi perusahaan belum terkomputerisasi oleh karena itu perusahaan belum memiliki database yang dapat menampung transaksi yang terjadi; (4) adanya kemungkinan terjadinya fraud di dalam penghargaan konstruksi karena harga konstruksi disediakan oleh bagian produksi dan ereksi.

Dengan adanya sistem yang baru diharapkan dengan sistem terkomputerisasi yang telah dirancang, diharapkan dapat mempermudah dan meningkatkan pengendalian atas sistem penjulan dan penerimaan kas. Sistem dapat mengatasi ketidak teraturan dalam penomeran dokumen karena penomeran dokumen dilakukan secara otomatis. Aktivitas pada bagian yag terlibat dalam proses penjualan dan penerimaan kas menjadi terkomputerisasi dengan baik, sehingga data transaksi dapat disimpan dalam database. Sistem melakukan pemrosesan harga konstruksi berdasarkan spesifikasi konstruksi yang diberikan bagian produksi dan ereksi. Jadi harga konstruksi tidak didapat dari bagian produksi dan ereksi melainkan diproses melalui sistem. Perusahaan ini menjual produk hoist merek Kone untuk dipasarkan di Indonesia. Produk hoist yang dijual adalah hoist tipe Electric Wire Rope Hoist, Elektric Chain Hoist, dan Chain Block. Perusahaan juga memproduksi konstruksi yang digunakan untuk hoist yang dijual. Konstruksi yang diproduksi adalah Overhead Crane, Gantry Crane, Monorail, Wall Jib Crane, dan Cargo Lift.

\section{HASIL DAN PEMBAHASAN}

\section{Prosedur Penjualan}

Bagian Penjualan menerima pemesanan dari Pelanggan melalui telpon atau Email. Bagian penjualan menghubungi pemasok untuk meminta performa invoice. Apabila pesanan termasuk konstruksi, maka spesifikasi konstruksi yang diberikan pelanggan diteruskan ke bagian produksi \& ereksi untuk mendapatkan harga konstruksi. Setelah menerima performa invoice, dan menerima kalkulasi harga dari bagian produksi \& ereksi, bagian Penjualan Membuat Surat Penawaran yang akan diberikan kepada pelanggan. Surat penawaran ini berisi daftar harga item yang dipesan pelanggan. Setelah menerima Surat Penawaran, pelanggan membuat Purchase Order untuk diberikan ke perusahaan. Purchase order tersebut diteruskan ke bagian pembelian \& copyannya diteruskan ke bagian produksi \& ereksi. Purchase Order berisi daftar item yang dipesan pelanggan.

Bagian penagihan membuat surat penagihan pembayaran down payment pelanggan. Bagian Penagihan menerima konfirmasi pembayaran dari pelanggan. Pada tanggal yang dijanjikan, pelanggan melakukan pembayaran down payment dengan giro atau uang tunai. Setelah terima pembayaran 
pelanggan, kasir membuat kwitansi pembayaran sebagai bukti pembayaran pelanggan. Setelah konstruksi selesai diproduksi, Bagian Akuntansi menerima laporan produksi selesai dari workshop. Kemudian bagian penagihan membuat surat tagihan untuk pelanggan. Bagian Penagihan menerima konfirmasi pembayaran dari pelanggan. Pada tanggal yang dijanjikan, pelanggan melakukan pembayaran down payment dengan giro atau uang tunai. Setelah terima pembayaran pelanggan, kasir membuat kuitansi pembayaran sebagai bukti pembayaran pelanggan dan bagian Akuntansi membuat Surat Jalan sebanyak 3 rangkap untuk bagian logistik sebagai dasar pengiriman item. Bagian Logistik \& pengiriman melakukan pengiriman item ke pelanggan. Setelah menerima item, pelanggan kemudian menendatangani Surat Jalan. Rangkap pertama diberikan ke customer, dan rangkap kedua diteruskan ke bagian akuntansi untuk arsip, sedangkan rangkap ke tiga diarsip oleh bagian logistik. Setelah item diterima oleh pelanggan, bagian Erection melakukan instalasi atas crane, hoist, dan grider. Setelah selesai melakukan instalasi bagian erection membuat laporan instalasi selesai untuk diberikan ke bagian akuntansi sebagai dasar penagihan pembayaran ke tiga.

Bagian penagihan membuat surat tagihan ke pelanggan. Setelah pelanggan menerima surat tagihan, pelanggan menghubungi perusahaan untuk memberikan konfirmasi pembayaran. Pada tanggal yang dijanjikan, pelanggan melakukan pembayaran dengan giro atau uang tunai. Kemudian kasir mengeluarkan kwitansi pembayaran. Semua giro yang diterima dicairkan ke bank dan uang tunai disetor ke rekening perusahaan.

\section{Permasalahan yang Dihadapi}

Penomeran dokumen transaksi dilakukan secara manual dengan menggunakan stempel penomeran sehingga pelacakan dokumen sering rancu. Masing masing dokumen memiliki stempel sendiri sehingga dalam penggunaannya terkadang sering tertukar. Tidak ada prosedur yang melakukan pengendalian terhadap limit kredit pelanggan sehingga, kemungkinan terjadinya kredit yang macet cukup tinggi. Belum adanya database untuk menyimpan transaksi penjualan dan penerimaan kas. Selama ini data data transaksi dan laporan disimpan dalam file berbentuk Microsoft Excel dalam hardisk komputer. Untuk transaksi pemesanan konstruksi, bagian penjualan mengalami masalah penawaran harga ke pelanggan. Seringkali harga yang ditawarkan ke pelanggan tidak sesuai dengan yang ada di lapangan karena penawaran diberikan sebelum adanya survey lapangan dari bagian perencanaan. Penghargaan konstruksi hanya terbatas pada kriteria site yang dijelaskan pelanggan pada saat pemesanan.

\section{Usulan Pemecahan Masalah}

Diadakannya suatu otomatisasi prosedur secara terkomputerisasi yang dapat menangani penomeran dokumen transaksi. Dibuatkan suatu otomasi fungsi yang mengkalkulasikan total faktur pelanggan yang belum lunas kemudian membandingkannya dengan limit kredit pelanggan. Dari hasil perbandingan tersebut kemudian didapat status pesanan pelanggan diterima atau ditolak. Merancang sistem database yang dapat mengolah data transaksi perusahaan. Sebelum memberikan penawaran konstruksi, bagian penjualan membuat surat perintah survey ke bagian perencanaan untuk mengetahui spesifikasi konstruksi yang diperlukan pelanggan. Setelah melakukan survei, bagian perencanaan memberikan spesifikasi konstruksi ke bagian penjualan. Kemudian untuk mendapatkan harga konstruksi, bagian penjualan menginput spesifikasi konstruksi ke dalam sistem. Sistem akan memproses harga konstruksi.

\section{Rancangan Sistem yang Diusulkan}

\section{Usulan prosedur yang baru}

\section{Prosedur Penjualan}


Bagian penjualan menerima pesanan dari pelanggan melalui telpon, fax atau email. Atas dasar pesanan tersebut, bagian penjualan memasukan kode pelanggan untuk memeriksa limit kredit pelanggan yang sudah ditentukan sebelumnya dengan total faktur pelanggan yang belum lunas. Sistem akan mengecek data dalam database dan hasilnya adalah sebuah tampilan yang berisi ditolak atau diterimanya pesanan pelanggan dan berapa jumlah pembelian yang dapat dilakukan pelanggan. Apabila pesanan pelanggan ditolak oleh sistem, maka bagian penjualan akan langsung mengkonfirmasikannya ke pelanggan.

Apabila pesanan diterima oleh sistem, maka bagian penjualan akan memasukan data pesanan pelanggan dalam sistem .Setelah data pesanan pelanggan dimasukan dalam form pesanan sistem, sistem akan mengeluarkan tampilan yang berisi data pemasok yang memasok hoist yang dipesan pelanggan. Atas dasar tampilan ini bagian penjualan menghubungi pemasok untuk memeriksa apakah barang yang dipesan pelanggan tersedia atau tidak dan berapa harganya. Apabila pesanan termasuk konstruksi, maka sistem akan mengeluarkan surat perintah survey untuk bagian perencanaan. Apabila hoist tidak tersedia di pemasok, maka pesanan akan ditolak dan akan dikonfirmasikan ke pelanggan melalui telepon, fax atau email. Setelah perusahaan telah menerima performa invoice dari pemasok dan pelanggan telah menyetujui draft rancangan konstruksi dari bagian perencanaan, maka bagian penjualan akan membuat surat penawaran ke pelanggan melalui sistem yang baru.

Setelah pelanggan menyetujui penawaran, maka bagian penjualan menerima purchase order dari pelanggan melalui telepon, fax atau e-mail. Atas dasar purchase order tersebut maka bagian penjualan akan mengisi form penjualan yang ada di sistem. Purchase order diteruskan ke bagian pembelian. Setelah bagian penjualan mengisi form penjualan, sistem yang baru akan membuat faktur penjualan sebanyak 2 rangkap. Rangkap 1 untuk bagian accounting sebagai dasar penagihan pembayaran 1, kemudian faktur tersebut diarsip oleh bag accounting; rangkap 2 untuk pelanggan.

\section{Prosedur Penerimaan Kas}

Proses ini dijalankan atas dasar terms and conditions yang disampaikan dalam surat penawaran, yaitu pembayaran pertama sebesar $50 \%$ sebagai down payment pada saat pelanggan memberikan porchase order, pembayaran ke dua sebesar $40 \%$ pada saat barang siap dikirim, dan pelunasan $10 \%$ pada saat selesai instalasi.

Atas dasar yang ditentukan, bagian penagihan membuat surat tagihan melalui sistem yang baru. Bagian penagihan menerima konfirmasi pembayaran dari pelanggan melalui telepon, fax atau email kemudian mencatatnya dalam sistem. Pada tanggal yang dikonfirmasikan tersebut, sistem secara otomatis mengeluarkan pesan pembuatan kwitansi ke bagian keuangan. Bagian keuangan membuat bukti pembayaran melalui sistem kemudian mencetaknya. Bukti pembayaran kemudian diteruskan ke bagian penagihan untuk disampaikan ke pelanggan. Bagian penagihan kemudian menerima giro atau uang tunai dari pelanggan. Giro atau uang tunai tersebut kemudian diteruskan ke bagian keuangan.

\section{Diagram Konteks}

Diagram hubungan atau diagram konteks adalah diagram yang menggambarkan sistem secara keseluruhan yakni menggambarkan sistem dengan dunian luarnya (eksternal entity) dan seluruh input ke output sistem (lihat Gambar 1).

\section{Diagram Nol}

Diagram Nol adalah diagram yang menggambarkan proses proses yang utama dari sistem informasi penjualan dan penerimaan kas pada diagram hubungan dan data store yang digunakan. Diagram ini digunakan dengan cara memecah atau membagi diagram hubungan menjadi beberapa 
fungsi penting yang dikerjakan dalam sistem. Pada diagram ini terlihat jelas masing masing hubungan antar proses, proses dengan entitas dan proses dengan data store yang digunakan (lihat Gambar 2).

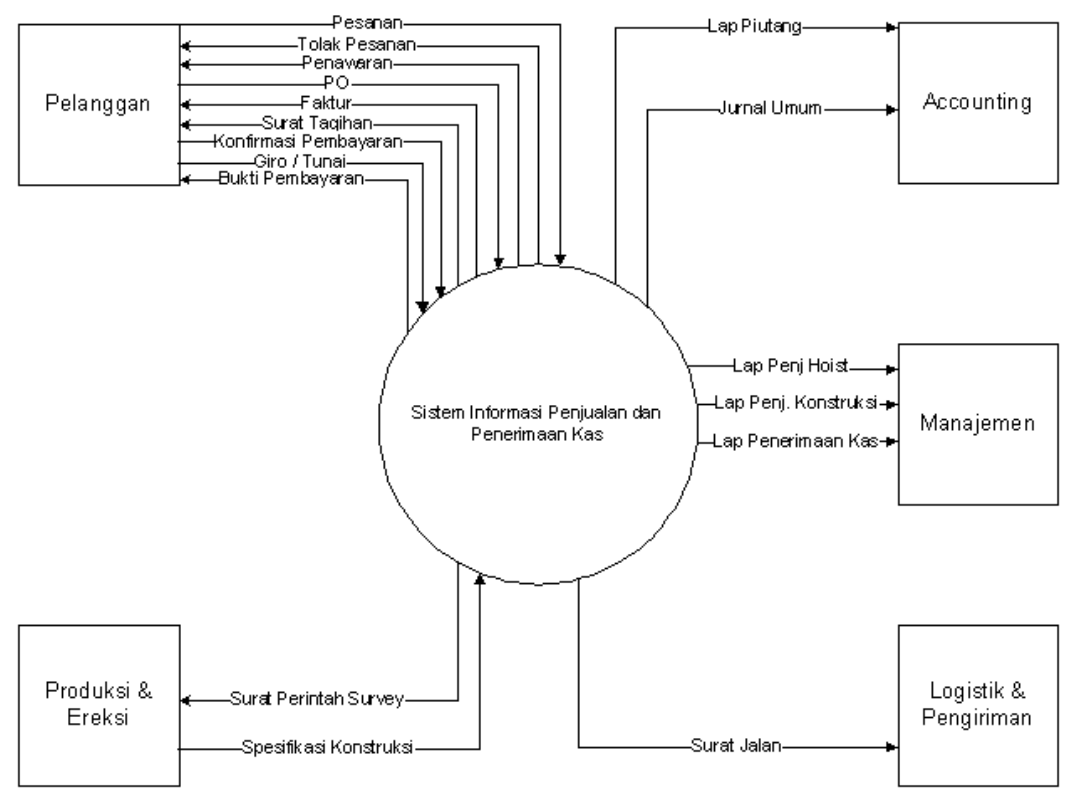

Gambar 1 Diagram Konteks Sistem yang diusulkan

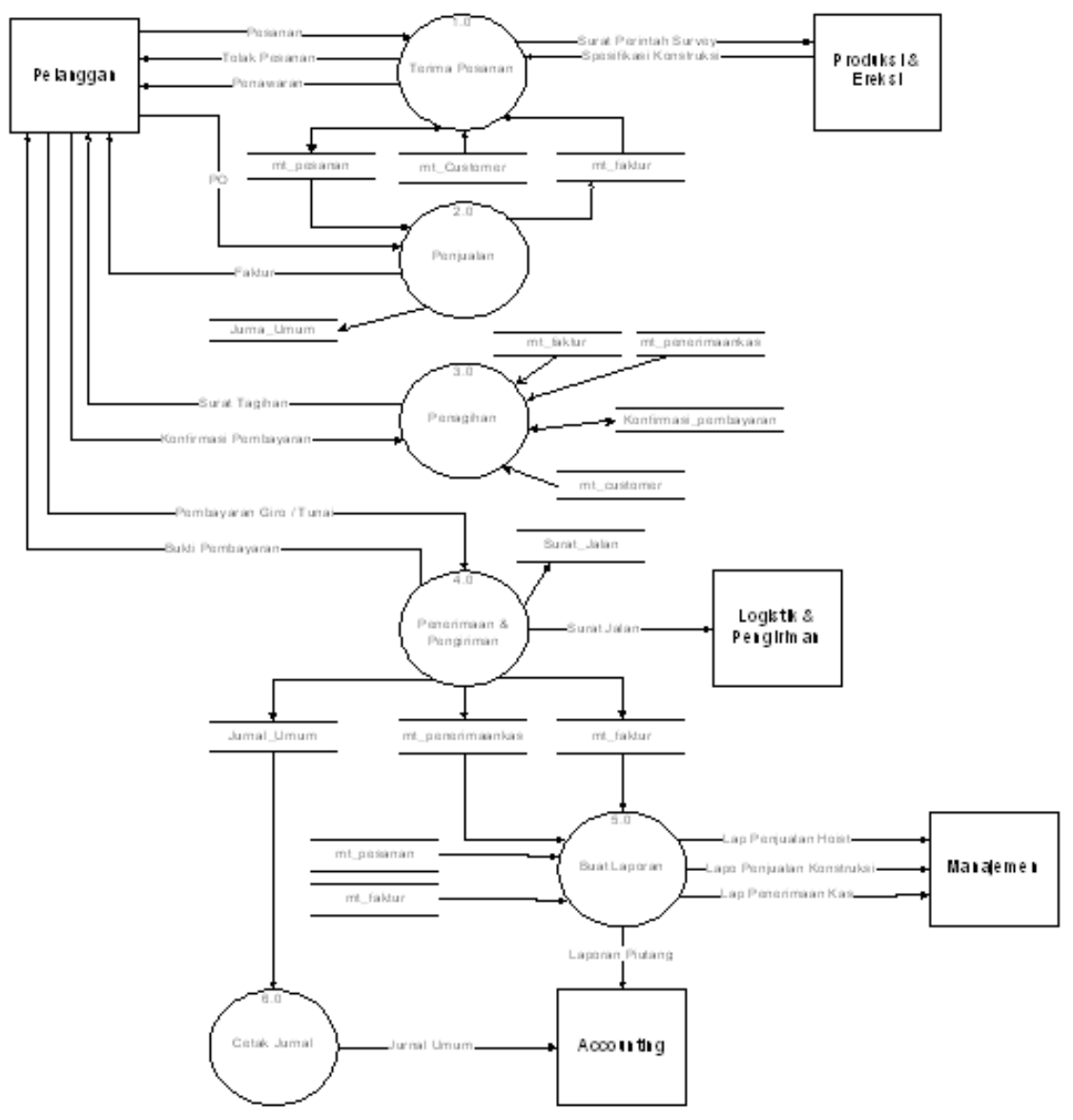

Gambar 2 Diagram Nol Sistem yang Diusulkan 


\section{Batasan User}

Batasan User sesuai dengan Jabatannya adalah sebagai berikut:

\begin{tabular}{|c|c|c|}
\hline Jabatan & Hak Akses Menu & Aktivitas \\
\hline Admin & Database Log User & Melihat Aktivitas user. \\
\hline Akuntansi & $\begin{array}{l}\text { Database Hoist, Konstruksi, } \\
\text { Pemasok, Pelanggan, Pesanan } \\
\text { Hoist, Pesanan Konstruksi, Menu } \\
\text { laporan \& Cetak Jurnal }\end{array}$ & $\begin{array}{l}\text { Melihat, menambahkan \& } \\
\text { mengedit database Hoist, } \\
\text { Konstruksi, Pemasok, \& } \\
\text { Pelanggan. Melihat Pesanan hoist } \\
\text { dan Pesanan konstruksi } \\
\text { pelanggan. Membuat laporan ke } \\
\text { manajemen dan mencetak jurnal } \\
\text { umum. }\end{array}$ \\
\hline Penjualan & $\begin{array}{l}\text { Transaksi Pesanan, Penawaran, } \\
\text { \& Penjualan }\end{array}$ & $\begin{array}{l}\text { Memasukan data pesanan } \\
\text { pelanggan, membuat surat } \\
\text { penawaran, dan membuat faktur. }\end{array}$ \\
\hline Penagihan & Transaksi Penagihan & Membuat surat tagihan \\
\hline Kasir & Transaksi Pembayaran Pelanggan & Membuat bukti pembayaran \\
\hline
\end{tabular}

\section{SIMPULAN}

Berdasarkan hasil analisis yang telah kami lakukan mengenai sistem penjualan dan penerimaan kas pada Perusahaan, maka kami memberikan kesimpulan bahwa keadaan Perusahaan yaitu (1) perusahaan menggunakan sistem penjualan berdasarkan pesanan dalam kegiatan usahanya dan sistem persediaan perusahaan adalah berdasarkan just in time; (2) hanya beberapa dokumen yang digunakan dalam transaksi penjualan perusahaan sudah bernomor urut tercetak. Penomeran ini dilakukan dengan menggunakan stempel penomeran manual; (3) sistem informasi akuntansi perusahaan belum terkomputerisasi oleh karena itu perusahaan belum memiliki database yang dapat menampung transaksi yang terjadi; (4) adanya kemungkinan terjadinya fraud di dalam penghargaan konstruksi karena harga konstruksi disediakan oleh bagian produksi dan ereksi. Dengan adanya sistem yang baru diharapkan dengan sistem terkomputerisasi yang telah dirancang, diharapkan dapat mempermudah dan meningkatkan pengendalian atas sistem penjulan dan penerimaan kas. Sistem dapat mengatasi ketidak teraturan dalam penomeran dokumen karena penomeran dokumen dilakukan secara otomatis. Aktivitas pada bagian yag terlibat dalam proses penjualan dan penerimaan kas menjadi terkomputerisasi dengan baik, sehingga data transaksi dapat disimpan dalam database. Sistem melakukan pemrosesan harga konstruksi berdasarkan spesifikasi konstruksi yang diberikan bagian produksi dan ereksi. Jadi harga konstruksi tidak didapat dari bagian produksi dan ereksi melainkan diproses melalui sistem.

\section{DAFTAR PUSTAKA}

Bodnar, G. H., \& Hopwood, W. S. Accounting Information System (8th ed.). Prentice Hall International.

Connolly, T. M., \& Begg, C. E. Database System a Pratical Approach to Design, Implementation, and Management (3rd ed.). Edinburg Gate, Harlow: Pearson Education Limited.

Cushing, B. E. Terjemahan R. Kosasih. (1994). Sistem Informasi Akuntansi dan Organisasi Perusahaan (3rd ed.). Jakarta: Penerbit Erlangga. 
Gibson, C. H. (1995). Financial Statement Analysis: Using Financial Accounting Information (6th ed.). Cincinnati, Ohio: South Western Collage Publishing.

Hall, J. A. (2001). Sistem Informasi Akuntansi. Jakarta: Salemba Empat.

Jogiyanto, H. M. (1997). Analisis dan Desain Sistem Informasi: Pendekatan Terstruktur (3rd ed.). Yogyakarta: Andi Offset.

Mcleod, Jr., R. Terjemahan H. Teguh. (2001). Sistem Informasi Manajemen Jilid 2 (7th ed.). Jakarta: Penerbit Prenhallindo.

Mulyadi. (2001). Sistem Akuntansi (3rd ed.). Jakarta: Salemba Empat.

Munk-Madsen, A., Stage, J., Mathiassen, L., \& Nielsen, P. A. (2000). Object Oriented Analysis \& Design (1st ed.). Denmark: Marko.

Romney, S. (2003). Accounting Information System (9th ed.). New Jersey: Prentice Hall.

Wilkinson, J. W. Terjemahan Agus M. (1993) Sistem Akuntansi dan Informasi. Jakarta: Penerbit Binapura Aksara. 